\title{
THE SCHEINFELD CENTER FOR HUMAN GENETICS IN THE SOCIAL SCIENCES
}

\author{
At The Hebrew University of Jerusalem
}

The growing interest in human genetics among social scientists has prompted the establishment of a new Center at The Hebrew University, through the medium of the American Friends of The Hebrew University.

Endowed by Mrs. Aaron Scheinfeld of Chicago in memory of her late husband (who was chairman of Manpower Inc.), and in honor of his brother Amram (author of many books on human genetics), the new educational unit has been named the "Scheinfeld Center for Human Genetics in the Social Sciences".

The Center will offer courses and seminars in human genetics especially oriented toward students of psychology, sociology, anthropology, and education. It will also subsidize research in such areas as human behavioral genetics, sex-differences, twin studies, human growth and development, and physical features. The underlying emphasis will be on normal human traits and behavior, as distinguished from pathological conditions, and on clarifying the interacting influences of heredity and environment in producing variation among human beings.

The Scheinfeld Center will be affiliated with the Faculty of Social Sciences of the Hebrew University, but will cooperate in its activities with all interested departments or individuals at the Hebrew University or elsewhere. The Center will be under the guidance of a specially appointed Board of Directors. It will formally begin its activities in November 1973, with the opening of the $1973 / 74$ academic year at The Hebrew University.

Correspondence may be addressed to:

Ruth Guttman, Ph.D.

Coordinator, The Scheinfeld

Center for Human Genetics in the Social Sciences

Department of Psychology

The Hebrew University of Jerusalem Jerusalem, Israel 


\section{5e CONGRES DE LA FEDERATION DES SOCIETES DE GYNECOLOGIE ET D'OBSTETRIQUE DE LANGUE FRANCAISE}

Convention chairman: Dr. Pierre Audet-Lapointe, Montreal, Canada. General reviewer: Professor Roger Vakaer, Belgium.

The congress comittee is also formed by doctors: Raymond Amyot, Rodrigue Bruyère, Lise Fortier, Bernard Lambert, Julien Lord, Jacques Lorrain and Jacques Vigeant, all from Montreal.

DATE: $\quad$ 24-28 September 1974

WHERE: $\quad$ Reine-Elizabeth Hotel, Montreal, Canada.

GENERAL THEME: New findings and most recent exploration methods in obstetrics and gynecology.

COLLOQUIA:

Amniotic fluid

The foeto-placenthal unit

Labor

Hypothalamo-hypophyseal axis

Cancer

ROUND TABLES:

Localisation of the placenta

Pregnant woucer

Breast

FREE COMMUNICATIONS
POST-GRADUATE COURSES:

Infertility

Neonatology

Contraception

Cancer

LUNCHEON CONFERENCES

EXHIBITS

FILMS PROJECTION

CALL FOR PAPERS AND ABSTRACT DEAD LINES: 1 April 1974

Information: 2065 rue Alexandre-Desève

Montréal 133

Province de Québec

Canada 
64th Annual Meeting of the

\section{AMERICAN PSYCHOPATHOLOGICAL ASSOCIATION}

7-8 March 1974

Sheraton-Boston Hotel, Prudential Center, Boston, Mass. 02199

Topic: Evaluation of Psychological Therapies

Sessions: Psychoanalysis and Psychotherapy

Aspects of Behavior Therapy

Combined Drug and Psychological Therapies

Papers with panel discussions

For information: Jonathan Cole, M.D. Secretary

Boston State Hospital

591 Morton Street

Boston, Massachusetts 02124 


\section{Journal de Génétique Humaine}

Publié par A. Franceschetti † (Genève), L. van Bogaert (Anvers) et M. Lamy (Paris). Secrétaire: D. Klein, Institut Universitaire de Génétique Médicale, 8, Chemin Thury, 1206 Genève.

Vol. 21 , No 1

Mars 1973

A.W. Eriksson and H. Forsius: Vitelliform macular degeneration.

P. Kissel, J.M. André et $M$. André: Coexistence dans la même famille d'un syndrome de Sjögren-Larsson et d'un syndrome de Rud.

B. Noël, Josiane Mottet, Yvette Nantois et Bernadette Quack: Contribution à l'identification du petit chromosome submétacentrique surnuméraire dans le syndrome des yeux de chat.

Catherine Pellié, J. Feingold et J. Demos: Age parental et mutation à propos d'une enquête sur la myopathie de Duchenne de Boulogne.

R. Walbaum, M.F. Vandevelde-Staquet, Ch. Lefebvre, D.K. Gnamey, B. Delattre et D. Leconte: Syndrome $48, \mathrm{XXXX}$ chez un nourrisson.

D. Klein: Le Questionnaire génétique (Conseil génétique pour un malade présentant l'association complexe d'un déficit en G-6-PD, d'un syndrome de Grönblad-Strandberg et d'une épilepsie).

Analyses de livres.

Parution: quatre numéros par année.

Abonnement: Fr. S. 50.-

\section{ÉDITIONS MÉDECINE ET HYGIÈNE}

78, Avenue de la Roseraie

1211 GENÈVE 4 / Suisse 